\title{
Cidade-empresa e controle da mão de obra na construção da usina hidrelétrica de Tucuruí (1974-1984)
}

\section{Company town and labour control in construction of Tucuruí hydroelectric (1974-1984)}

\section{Nathalia Capellin Carvalho de Oliveira*}

Resumo: A barragem hidrelétrica de Tucuruí foi construída nas margens do rio Tocantins, no Pará, entre 1974 e 1984. Este artigo trata da implantação de uma verdadeira sociedade da barragem através da instalação de uma cidade-empresa para abrigar os diversos trabalhadores e trabalhadoras implicados nessa construção. Aqui, partiremos da lógica empresarial e institucional para tratar da implantação, organização e funcionamento desse espaço particular, tentando por um lado caracterizar quem são as pessoas que participam da construção dessa barragem e refletir sobre a maneira como esse tipo de espaço controlado por uma empresa participa da disciplina dos corpos e da vida dos trabalhadores dentro e fora do canteiro, visando à maximização da produtividade. Como espaço de controle, inevitavelmente há reações que também farão parte desta análise. Esta pesquisa segue o curso das fontes institucionais e técnicas da construção de barragens para tentar caracterizar a implantação e a gestão de um canteiro de obras durante a ditadura militar.

Palavras-chave: Amazônia; cidade-empresa; hidrelétrica; ditadura militar.

Abstract: The Tucuruí hydroelectric dam was built on the Tocantins River in Pará between 1974 and 1984. This article deals with the establishment of the society of the dam through the installation of a company town, to house the various workers involved in this construction. Focusing on the institutional and entrepreneurial point of view, we will deal with the implantation, organization and functioning of this particular space, trying on the one hand to characterize

Doutora em História pela Université Paris Saclay. Pesquisadora no Laboratório Interdisciplinar de Avaliação de Políticas Públicas (LIEPP-Sciences Po) e associada ao laboratório Centre d'Histoire Culturelle des Sociétés Contemporaines (CHCSC-UVSQ) e professora na Paris Sorbonne-Université e Université Paris-Nord. ORCID: https://orcid.org/0000-0001-5692-5326. E-mail: nacapellini@gmail.com. 
who are the workers who participate in the construction of this dam. And on the other hand, to reflect upon the way in which this type of space controlled by a company participates in the discipline of bodies and workers' lives inside and outside the construction site, aiming at maximizing productivity. As a space of control, there are inevitably reactions that will also be part of this analysis. This research follows the course of the institutional and technical sources of the construction of dams to try to characterize the implementation and management of a construction site during the military dictatorship.

Keywords: Amazon; company town; hydroelectricity; military dictatorship.

\section{Introdução}

Q uando imaginamos uma usina hidrelétrica, é comum pensar na imagem de um rio atravessado por uma imensa estrutura de terra ou de concreto. Às vezes pensamos nas cachoeiras artificiais produzidas pela passagem da água através das comportas, gerando energia ou regulando o fluxo de um rio. Ou ainda nos enormes reservatórios onde alguma vez pescamos, passamos uma tarde ou vimos em vídeo ou fotografia. Ao lado dessas imagens, que são às vezes belas e idílicas, coexistem as imagens, hoje amplamente conhecidas, dos consideráveis impactos dessas infraestruturas, como peixes mortos, populações deslocadas ou árvores em decomposição.

Sejam elas positivas ou lastimosas, essas imagens em que pensamos quando evocamos uma hidrelétrica geralmente representam um momento final, capturado após um longo processo de construção, feito de sucessivas modificações na paisagem, no meio ambiente e nas relações humanas e não humanas que se desenrolam nesses espaços. Esse processo de construção de uma barragem ocorre em um lugar singular: o canteiro de obras. Em se tratando de megaprojetos em zonas mais ou menos isoladas, como no caso que trataremos aqui, diferentes configurações territoriais e demográficas são assim desordenadas e reordenadas pelos fluxos gigantescos de trabalhadores e trabalhadoras e materiais associados diretamente ou indiretamente a esses canteiros.

O projeto de construção de uma hidrelétrica em Tucuruí, cidade paraense situada às margens do rio Tocantins, surge em um contexto particular. Ele nasce da vontade geopolítica do Estado ditatorial que governou o Brasil de 1964 a 1985 de controlar e dominar o que ele percebia como as margens de seu território (a Amazônia), fazendo ele contribuir com o desenvolvimento econômico do país. Essa barragem está intimamente ligada à implantação de um complexo de produção de alumínio associado ao capital estrangeiro e teve muitos impactos negativos. A prolífica literatura sobre Tucuruí é exaustiva sobre as consequências sociais e ambientais dessa construção. ${ }^{1}$ Se a hidrelétrica Tucuruí foi um projeto de Estado,

1 Ver, por exemplo: FEARNSIDE, Philip M. Environmental Impacts of Brazil's Tucuruí Dam: Unlearned Lessons 
localmente são as milhares de pessoas que vieram para construir a barragem, ou tentar a sorte no entorno do projeto, que dão o tom das mudanças ocorridas, uma dimensão ainda pouco aprofundada nos estudos historiográficos sobre projetos hidrelétricos. ${ }^{2}$

Este artigo trata dos efeitos muito localizados da instalação do canteiro de obras na cidade de Tucuruí e da construção de uma verdadeira sociedade da barragem através da instalação de uma company town, uma cidade-empresa, para abrigar os diversos trabalhadores e trabalhadoras implicados nessa construção. A cidade-empresa será aqui entendida ao mesmo tempo enquanto território e população; enquanto uma estrutura material e uma unidade de vida coletiva; e enquanto configurações de objetos físicos e nós de relacionamento entre sujeitos sociais. ${ }^{3}$ Assim, tratarei da implantação, organização e funcionamento dessa cidade-empresa, para, por um lado, caracterizar quem são os trabalhadores e trabalhadoras que participaram da construção dessa barragem, e por outro, refletir sobre a maneira como esse tipo de espaço controlado por uma empresa privada (Camargo Corrêa), em conjunto com uma empresa estatal (Eletronorte), participa da disciplina dos corpos e da vida dos trabalhadores dentro e fora do canteiro, visando à maximização da produtividade e à concretização de um projeto de Estado. Como espaço de controle, inevitavelmente há reações que também farão parte desta análise. No entanto, contrariamente ao enfoque mais frequente da história social do trabalho, que busca visibilizar a agência dos trabalhadores como sujeitos históricos e seus movimentos reivindicativos, levando em conta tanto os fenômenos socioculturais quanto o papel do indivíduo, ${ }^{4}$ o seguinte artigo se concentra em destrinchar a lógica empresarial que modela a gestão e o controle da mão de obra nos canteiros estatais da ditadura brasileira. Esse recorte foi delineado pela coleção de fontes que compõe esse estudo.

Para reconstruir o canteiro de Tucuruí e a sua cidade-empresa, fiz amplo uso de obras institucionais de memória da empresa, que oferecem relatos muito detalhados e numerosas imagens e dados sobre o projeto..$^{5}$ A partir desses trabalhos institucionais, esse trabalho se

for Hydroelectric Development in Amazonia. Environmental Management, v. 27, n. 3, p. 377-396, 2001; MAGALHÃES, Sônia B. O desencantamento da beira - reflexões sobre a transferência compulsória provocada pela Usina Hidrelétrica de Tucuruí. In: MAGALHÃES, Sônia B.; BRITTO, Rosyan C.; CASTRO, Edna M. R. de (org.). Energia na Amazônia. V. 2. Belém: MPEG/UFPA/Associação de Universidades Amazônicas, 1996. p. 697-746; ACSELRAD, Henri. Planejamento autoritário e desordem socioambiental na Amazônia: crônica do deslocamento de populações em Tucuruí. Revista de Administração Pública, Rio de Janeiro, v. 25, n. 4, p. 53-68, 1991; MOUGEOT, L. Planejamentos hidroelétrico e reinstalação de populações na Amazônia: primeiras lições de Tucuruí, Pará. In: AUBERTIN, Catherine; BECKER, B. (org.). Fronteiras. Brasília: Universidade de Brasília, 1988.

2 RIBEIRO, Maria de Fátima Bento. Memórias do concreto: vozes na construção de Itaipu. Cascavel: Edunioeste, 2002. Sublinho aqui os trabalhos de Gilberto Rocha que constituem uma contribuição importante para a compreensão dos processos territoriais que se desencadeiam com construção dessa barragem: ROCHA, Gilberto de M. Todos convergem para o lago! Hidrelétrica Tucuruí. Municípios e territórios na Amazônia. Belém: NUMA/UFPA, 2008; TRINDADE JR., Saint-Clair Cordeiro da; ROCHA, Gilberto de M. Cidade e empresa na Amazônia: gestão do território e desenvolvimento local. Belém: Editora Paka-Tatu, 2002.

3 GRAFMEYER, Yves; AUTHIER, Jean-Yves. Sociologie urbaine. Paris: Armand Colin, 2008. p. 11.

4 BATALHA, Cláudio. A historiografia da classe operária no Brasil: trajetórias e tendências. In: FREITAS, M. C. (org.). Historiografia Brasileira em Perspectiva. São Paulo: Contexto, 2007. p. 145-158.

5 Refiro-me aqui à "memória do projeto" em oito volumes de Tucuruí, publicada em 1988, e a um volume de memória técnica de 681 páginas publicado em 1989, ambos editados pela Eletronorte e Eletrobrás sob ordens 
interessa pela maneira como esses elementos são apresentados nesses documentos, na medida em que eles fornecem informações sobre a obra e seu processo de construção. Este trabalho também se baseia nos numerosos artigos publicitários e peças de comunicação da Eletronorte em torno da construção em Tucuruí. Paralelamente à análise de trabalhos publicados, segui os caminhos da literatura cinzenta produzida pela Eletronorte, ou seja, diversos relatórios e documentos nunca publicados, assim como trabalhos feitos por instituições e empresas de pesquisa e consultoria que participaram da obra. No entanto, muitas lacunas permanecem, principalmente em relação a informações que permitiriam realizar uma história desde abaixo, abarcando o ponto de vista dos trabalhadores e trabalhadoras que participaram dessa obra, como entrevistas ou fontes oriundas da Justiça do Trabalho que não fizeram parte do conjunto de documentos aqui analisados.

\section{A construção de Tucuruí}

Desde o finAL do sÉCULO DEZENOVE a hidroeletricidade foi o modelo privilegiado pelo Brasil para a geração de energia elétrica no país. Porém, a construção de barragens na Amazônia só começa mesmo durante a ditadura militar (1964-1985), período onde essa região é investida pela ação federal através de planos de desenvolvimento, agências estatais e projetos de infraestrutura. A partir do regime militar, dois objetivos principais caracterizam a estratégia do Estado para a região: desenvolvimento e segurança. Nesse contexto, a hidroeletricidade proveniente das águas da Amazônia deveria fornecer a energia necessária ao desenvolvimento econômico do país, favorecendo a instalação de grandes usinas eletrointensivas e projetos de extração mineral na região, além de ajudar na ocupação do vasto território visto como "vazio".

O exemplo emblemático dos primeiros passos na construção de barragens hidroelétricas na Amazônia é o da barragem de Tucuruí (UHE Tucuruí), no rio Tocantins, no estado do Pará. A hidrelétrica de Tucuruí, que começou a ser construída em 24 de novembro de 1974 e entrou em operação no dia 22 de novembro de 1984, foi a primeira barragem desse porte a ser construída em uma área de floresta tropical úmida, ${ }^{6}$ e permanece até hoje uma das maiores barragens do mundo. Essa obra mobilizou mais de 25 mil trabalhadores e trabalhadoras, 700 máquinas e é hoje a principal usina geradora do subsistema Norte do Sistema Interligado Nacional de energia, gerando hoje em média 8.370 MW.

do Departamento Nacional de Águas e Energia Elétrica (DNAEE).

6 As outras barragens de dimensões menores que já tinham sido (ou estavam sendo) construídas na Amazônia eram então a de Brokopondo, no Suriname, inaugurada em 1964, Coaracy Nunes, inaugurada no Amapá, em 1975, e Curuá Una, inaugurada no Pará, em 1977. 
Figura 1: localização da UHE Tucuruí e empreendimentos anexos

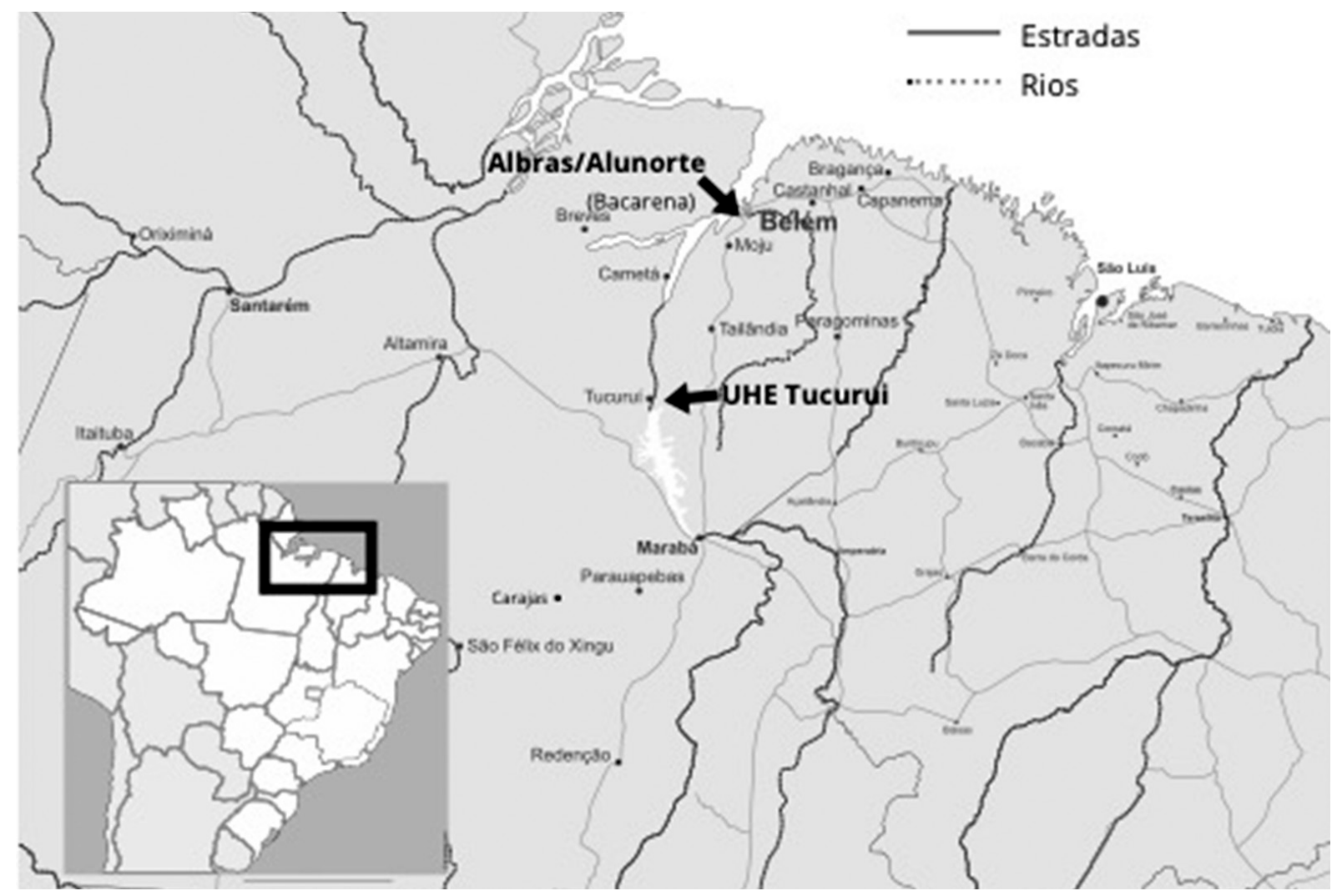

Fonte: Fundo cartográfico d-maps.com, modificado pela autora.

O projeto da UHE Tucuruí começou a tomar forma na busca de uma solução para o abastecimento elétrico da cidade de Belém. A partir de 1968 foram realizados, sob a coordenação da Eletrobrás, diversos estudos pela Coordenação de Estudos Energéticos da Amazônia $(\text { Eneram })^{7}$ para investigar o potencial de aproveitamento hidrelétrico nas áreas prioritárias de investimento do governo federal na região amazônica, os "polos de desenvolvimento". O Eneram confirmou em sua conclusão um potencial de exploração gigantesco existente em torno da área das cachoeiras de Itaboca, perto do município de Tucuruí. ${ }^{8}$ Porém, naquele momento, as necessidades de Belém não eram compatíveis com o tamanho do potencial revelado pelo estudo e o setor da construção civil possuía pouca experiência na construção de uma represa hidrelétrica do porte do potencial revelado na Amazônia.

Tudo isso mudou no final de 1973, quando o Brasil começou a negociar com empresas japonesas a construção de um complexo industrial de alumínio para transformar a bauxita descoberta em Oriximiná (Pará). As negociações com os empresários japoneses deram origem a uma joint venture entre a mineradora brasileira Companhia Vale do Rio Doce (CVRD) e a Nippon Light Metals Smelter's Association (NLMSA - uma associação formada pelas cinco maiores empresas produtoras de alumínio do Japão), para construir uma fábrica de alumina,

$7 \quad$ Criada pelo Decreto $n .^{\circ} 63.952$, de 31 de dezembro de 1968.

8 ENERAM; ELETROBRÁS. Relatório Final: conclusões e recomendações. s.l.: Eletrobrás, 1971. 
a Alumina Norte do Brasil (Alunorte) e uma outra de alumínio, a Alumínio Brasileiro (Albrás), em Bacarena (Pará). Essas usinas necessitavam um suprimento elevado e constante de eletricidade a um preço baixo para funcionar: elemento que era fundamental para a continuidade do projeto. No início, o consórcio japonês deveria arcar com pelo menos uma parte dos custos da barragem, já que seria seu principal consumidor. ${ }^{9}$ Posteriormente, a NLMSA retirou-se do financiamento da hidrelétrica e reduziu seu projeto de usina de alumínio. ${ }^{10}$ Porém, uma vez que surgiu a possibilidade de combinar extração mineral com implantação industrial, uma das linhas diretrizes do projeto de desenvolvimento da Amazônia do regime naquele momento, o governo decidiu arcar com os custos da construção da barragem hidrelétrica. ${ }^{11}$

No final de 1975, apenas um ano e meio após os estudos de viabilidade estabelecerem os primeiros esboços da barragem, começou a construção da UHE Tucuruí. A construtora Camargo Corrêa ganhou a primeira licitação referente ao estabelecimento do canteiro e o começo do desvio do rio Tocantins, o contrato foi assinado no início de novembro de 1975, e a primeira ensecadeira começou a ser construída alguns dias depois. ${ }^{12} \mathrm{O}$ projeto básico que definiu o projeto de engenharia da barragem foi concluído em julho de 1976, e a licitação para as obras principais da barragem foi lançada em março de 1976. A construtora Camargo Corrêa venceu novamente essa segunda licitação e foi contratada para as obras principais.

Uma megabarragem sempre transforma radicalmente o ambiente e a paisagem onde se implanta. Em Tucuruí essas transformações incluíram, por exemplo, nada menos do que $2.430 \mathrm{~km}^{2}$ inundados para a formação do reservatório, ou seja, uma área duas vezes maior do que cidade do Rio de Janeiro, coberta essencialmente por florestas. Da mesma forma, cerca de $170 \mathrm{~km}$ de rio foram transformados em um ambiente lacustre, o que mudou radicalmente a dispersão de sedimentos e a distribuição da fauna aquática pelo rio Tocantins. Mas a barragem em si não é a única a causar mudanças. O canteiro de obras também pressupõe numerosas e sucessivas transformações do espaço na sua implantação. Para que se desse início ao canteiro de obras de Tucuruí, foi desmatada uma área de pelo menos $191.840 \mathrm{~m}^{2}$, o equivalente a 26 campos de futebol, que teve o seu solo nivelado, compactado e tratado. ${ }^{13} \mathrm{Um}$ canteiro também causa um choque demográfico importante com a rápida multiplicação da população local. Entre

9 Para isso, foi aprovada uma lei especial em 10 de dezembro de 1973, permitindo investimentos privados em barragens na região amazônica.

10 Algumas fontes explicam o abandono do projeto hidrelétrico pelo consórcio japonês pela queda nos preços do mercado mundial de alumínio, outras culpam as constantes mudanças no cronograma da barragem que causavam aumentos nos custos de construção.

11 OLIVEIRA, Nathalia Capellini C. de. Historiciser les barrages en Amazonie brésilienne: environnement, conflit et politique dans la planification et la construction de Tucuruí (1960-1985). Tese (Doutorado em História) - Université de Versailles SQY, Versailles, 2019. Inicialmente a barragem custaria cerca de 700 milhões de dólares; em 1976, esse valor já atingiu 2,5 bilhões de dólares. Tucuruí acabou custando oficialmente mais de 5 bilhões de dólares, enquanto estimativas independentes colocam esse valor na faixa dos 7,5 bilhões a 10 bilhões de dólares.

12 Sobre o processo de licitação de Tucuruí, ver: CAMPOS, Pedro Henrique Pedreira. Ditadura, interesses empresariais e desenvolvimentismo: a obra da usina hidrelétrica de Tucuruí. Revista Tempo e Argumento, Florianópolis, v. 11, n. 26, p. 255-286, 2019.

13 Dados calculados a partir de : ELETRONORTE. Usina Hidrelétrica de Tucuruí - Memória Técnica. Brasília: Eletronorte, 1989. p. 278-283. 
os que chegam para participar da construção, assim como suas famílias, e os que vêm para tentar a sorte perto de um novo empreendimento, a população no entorno de grandes projetos tende a crescer exponencialmente, com todos os problemas que isso pode acarretar.

\section{Uma "cidade-empresa" para o canteiro}

Quando a Eletronorte chegou em Tucuruí, as cidades-empresas não eram um fenômeno completamente novo na Amazônia, mesmo que não fossem muito comuns. O estabelecimento dessas estruturas urbanas estava intimamente ligado aos grandes projetos de desenvolvimento (econômico ou infraestruturais) realizados por estrangeiros, pelo Estado ou por empresas nacionais. Devido à baixa taxa de urbanização na Amazônia, os locais de estabelecimento desses projetos eram quase sempre longe de centros urbanos. Assim, a implantação de uma cidade-empresa se prestava e às vezes até se impunha. Esse era particularmente o caso de projetos que necessitavam uma quantidade importante de mão de obra qualificada que viria de outras regiões. O objetivo era então atrair, e às vezes também fixar essas populações.

Rosa Elizabeth Acevedo Marin, no prefácio de um livro sobre cidades-empresas na Amazônia, destaca quatro características desse tipo de urbanização nessa região. ${ }^{14}$ Enquanto as três primeiras podem em realidade ser generalizadas para quase todo o tipo de urbanização desse tipo, a quarta é mais específica à região. Primeiramente as cidadesempresas representam uma extensão da linha de produção à qual estão vinculadas. Então, mesmo quando essas cidades são de circulação livre, seu design cria enclaves urbanos para garantir a atividade e o controle da força de trabalho. Em segundo lugar, essas cidades buscam estabelecer um ambiente autossuficiente por meio de um planejamento destinado a gerenciar o tempo produtivo e os espaços de sociabilidade dessa força de trabalho, tentando neutralizar o conflito, as tensões, mas também o surgimento de atores sociopolíticos. ${ }^{15} \mathrm{~A}$ terceira característica é a de uma forma mais ou menos autônoma - em termos políticos e/ou econômicos - de gestão territorial pelos responsáveis. Enfim, a quarta é como essas cidades-empresas na Amazônia representam uma negação dos padrões urbanísticos regionais tradicionais, por sua natureza, características e (particularmente) sua densidade técnica marcam uma forte diferença em relação aos arredores. ${ }^{16} \mathrm{~A}$ geógrafa Bertha Becker chamou esse fenômeno de "franjas urbanas avançadas", que operam em uma dinâmica de fronteira, introduzindo novos modelos na região. ${ }^{17}$ Além disso, como enfatiza José Sérgio Leite Lopes, o controle da vida além do trabalho foi ainda maior nas cidades-empresas da Amazônia (que o autor nomeia modelo "grande projeto-acampamento") do que em vilas

14 MARIN, Rosa Elizabeth Acevedo. Prefácio. In: TRINDADE JR, Saint-Clair C. da; ROCHA, Gilberto de M. (orgs.). Cidade e empresa na Amazônia: gestão do território e desenvolvimento local. Belém: Editora PakaTatu, 2002. p. 18.

15 MARIN, op. cit., p. 10-11.

16 BECKER, Bertha K. Amazônia. São Paulo: Ática, 1990.

17 Ibidem. 
operárias estabelecidas historicamente no setor açucareiro e têxtil e mais tarde industrial (siderurgia, metalurgia etc.), em virtude do maior isolamento. ${ }^{18}$

Com relação a esses espaços criados para e por empresas da Amazônia, o exemplo emblemático é o de Fordlândia, um experimento de Henry Ford para cultivar borracha para suas fábricas nos Estados Unidos, em Belterra, nas margens do rio Tapajós no Pará. Entre as décadas de 1920 e 1940, o industrial tentou transpor, em termos organizacionais, arquitetônicos e culturais, o seu modelo de cidade-empresa do Midwest estadunidense em plena floresta tropical. O projeto foi um grande fracasso, tanto para o cultivo de borracha, quanto no modelo social importado. Fordlândia está hoje abandonada e retomada pela vegetação, e constitui no melhor dos casos uma curiosidade que ocasionalmente atrai turistas, jornalistas, mas também artistas e fotógrafos para a região. Outros exemplos da criação de cidades-empresas na Amazônia incluem a implantação da Vila Massangana, no estado de Rondônia, na década de 1960, para a exploração de um depósito de estanho pela construtora Paranapanema. Ou ainda a construção da Vila Amazonas e da Serra do Navio como parte do projeto de exploração de manganês da ICOMI no Amapá, a partir 1957, e a cidade-empresa associada à barragem hidrelétrica de Coaracy Nunes no mesmo estado. Concomitantemente com o estabelecimento da Eletronorte em Tucuruí, também estavam sendo implantadas a Vila Carajás e Parauapebas, vinculadas à exploração de ferro em Carajás, o projeto de criação de gado na fazenda Vale do Cristalino, pela Volkswagen entre 1973 e 1986, ou ainda vila operária do projeto "irmão" de Tucuruí para a produção de alumínio em Bacarena.

A cidade de Tucuruí, anteriormente chamada Alcobaça, foi marcada historicamente por sua proximidade com as cachoeiras de Itaboca ${ }^{19}$. Devido à dificuldade da passagem de barcos pelo trecho, a cidade se configurou enquanto parada obrigatória no transporte fluvial (inter)regional pelo rio Tocantins ${ }^{20}$ Desde a criação da Estrada de Ferro Tocantins (EFT), ${ }^{21}$ para contornar o obstáculo à navegação mencionado, o transporte comercial de produtos de extração se torna uma das principais atividades dos habitantes dessa cidade e de seus arredores. Com o aumento do comércio de castanha-do-pará, Tucuruí torna-se um grande armazém comercial, localizado entre o principal centro produtor da época (Marabá) e o porto exportador na cidade de Belém. Com o regime militar e a intensificação de programas de desenvolvimento regional na Amazônia, como a "Operação Amazônia", a EFT e os armazéns

18 LOPES, Sérgio José Leite. Formas comparadas de imobilização da força de trabalho: fábricas com vila operária tradicionais e grandes projetos. Lusotopie, v. 3, n. 1, p. 285-298, 1996.

19 Alcobaça, fundada em 1789, tornou-se Tucuruí após 1947, com o Decreto Legislativo n. ${ }^{\circ} 4.505$, de 30 de dezembro de 1943.

20 DIAS, Catharina Vergolino. Aspectos Geográficos do Comércio da Castanha no Médio Tocantins. Revista Brasileira de Geografia, Rio de Janeiro, v. 21, n. 4, p. 517-531, 1959, p. 524.

21 Em 1890 foi criada a Companhia Ferroviária e Fluvial de Tocantins e Araguaia. A Estrada de Ferro Tocantins deveria ligar Alcobaça (Tucuruí) à Praia da Rainha, começou a ser construída em 1905, mas foi interrompida em 1916 por dificuldades financeiras. Até 1932 a ferrovia operou apenas ocasionalmente. Durante a década de 1930, o governo federal financiou a manutenção e a expansão da EFT até Jatobal, onde se concentrava uma parte importante da coleta de castanha-do-pará. A EFT operou até 1974, mas nunca de maneira totalmente eficiente ou contínua. 
de castanha-do-pará de Tucuruí são progressivamente abandonados em benefício de outras atividades econômicas e do transporte rodoviário. ${ }^{22}$

Antes da sua dissolução, a presença da EFT marcou profundamente essa pequena cidade amazônica. O estabelecimento da empresa ferroviária produziu um processo de urbanização do tipo company town, que foi repetido pela Eletronorte durante a construção de Tucuruí de maneira ainda mais rápida e radical. Contrariamente a outras cidades da região, já nos anos 1930 Tucuruí possuía construções em cimento, eletricidade, água corrente e um sistema de esgoto. Porém, essas infraestruturas existiam apenas na área ocupada pela empresa ferroviária e seus funcionários. No resto da cidade a infraestrutura era precária, não possuindo sistema de eletricidade, água ou esgoto. ${ }^{23}$

Quando o engenheiro Guido Rios, o primeiro funcionário da Eletronorte no local, chegou a Tucuruí em agosto de 1974, ele foi alojado em um prédio pertencente à antiga EFT. Rios conta que a sua casa também servia como escritório da Eletronorte, já que não havia infraestrutura adequada para seu trabalho e que o acesso à eletricidade era, na melhor das hipóteses, intermitente. Ainda segundo Rios, ele era obrigado a fazer todas as suas ligações para Brasília, sede da Eletronorte, a partir Belém, a cerca de 446 km de distância de Tucuruí. Essa viagem era impraticável em automóvel e muito lenta de barco. Rios viajava então a Belém com muita regularidade no avião particular da empresa. ${ }^{24}$ Mais de um ano depois, quando a Camargo Corrêa se instalou em Tucuruí para a construção da primeira ensecadeira em novembro de 1975, a construtura precisou alugar um barco para alojar os operários na ausência de outra estrutura de alojamento na cidade. ${ }^{25}$ Outros depoimentos colhidos na imprensa, ou ainda em entrevistas feitas com funcionários da Eletronorte para publicações comemorativas da empresa, destacam o que era então percebido como precário no local, como o fato de que as casas na cidade não possuíam banheiros ou a ausência de carros.

Esses relatos evocam um período imediatamente anterior ao estabelecimento da cidade-empresa da Eletronorte e revelam tanto os problemas que essa urbanização planejada devia supostamente compensar (como a ausência de moradia) quanto as diferenças entre a população que chega e a que vive no local. O espanto com a falta de instalações sanitárias é, por exemplo, um marcador das origens sociais e territoriais dos profissionais em questão, uma vez que, na realidade, essa ausência é extremamente comum na Amazônia, mas também em outros lugares do país na época, onde menos $30 \%$ das residências eram conectadas a um sistema de esgotos ou possuíam fossas sépticas. ${ }^{26}$ Esses testemunhos também apontam

22 VELHO, Otávio G. Frentes de expansão e estrutura agrária: estudo do processo de penetração numa área da Transamazônica. Rio de Janeiro: Centro Edelstein de Pesquisas Sociais, 2009.

23 LARAIA, Roque de Barros; MATTA, Roberto da. Índios e castanheiros: a empresa extrativa e os índios no Médio Tocantins. Rio de Janeiro: Paz e Terra, 1978. p. 88.

24 No TCO, três pioneiros contam a aventura do início da obra, Corrente Contínua, Brasília, ed. 100, p. 12, nov. 1985.

25 VASCONCELOS. Tucuruí: a nova luz da Amazônia. Revista Manchete, Rio de Janeiro, ed. 1522, p. 58-68, 20 fev. 1981

26 SAIANI, Carlos César Santejo; TONETO JÚNIOR, Rudinei. Evolução do acesso a serviços de saneamento básico no Brasil (1970 a 2004). Economia e Sociedade, Campinas, v. 19, n. 1, p. 79-106, 2010, p. 81. 
para grandes mudanças, nos anos 1970, no uso de certas tecnologias, muitas das quais foram implantadas na área pela cidade-empresa. Um exemplo é o estabelecimento de serviços telefônicos inexistentes localmente antes de 1975, outro é a introdução de voos comerciais entre Tucuruí e várias grandes cidades do país.

Além disso, os problemas encontrados pelos recém-chegados não eram apenas relacionados à (falta de) moradia e infraestrutura no local. O testemunho de um dos trabalhadores "pioneiros" é esclarecedor a esse respeito, pois a presença imponente da floresta e suas particularidades não eram fáceis a incorporar por uma população vinda de outros estados. Assim, ele sublinha a constante "luta contra os mosquitos" e o crepúsculo quando "tudo era assustador", razão pela qual "vários barrageiros tinham medo de morrer [...], tinha que ser macho para ficar". ${ }^{27}$ Também encontramos nesse depoimento a exaltação de características associadas à masculinidade, que marcam muitos discursos em torno de projetos de barragens, onde é frequentemente mencionada a coragem, força, espírito pioneiro, gosto pelo desafio, tanto em referência aos engenheiros quanto aos operários.

A primeira parte do espaço urbano de Tucuruí a ser gerenciado pela Eletronorte foi a Vila Pioneira. Por razões orçamentárias, ela foi concebida como um acampamento e não possuía uma infraestrutura separada da cidade de Tucuruí. No entanto, como a própria Eletronorte apontava, a infraestrutura urbana existente em Tucuruí já era insuficiente e precária sem o excedente populacional que iria trazer o canteiro. ${ }^{28}$

Figura 2 - Localização dos diferentes bairros da Eletronorte.

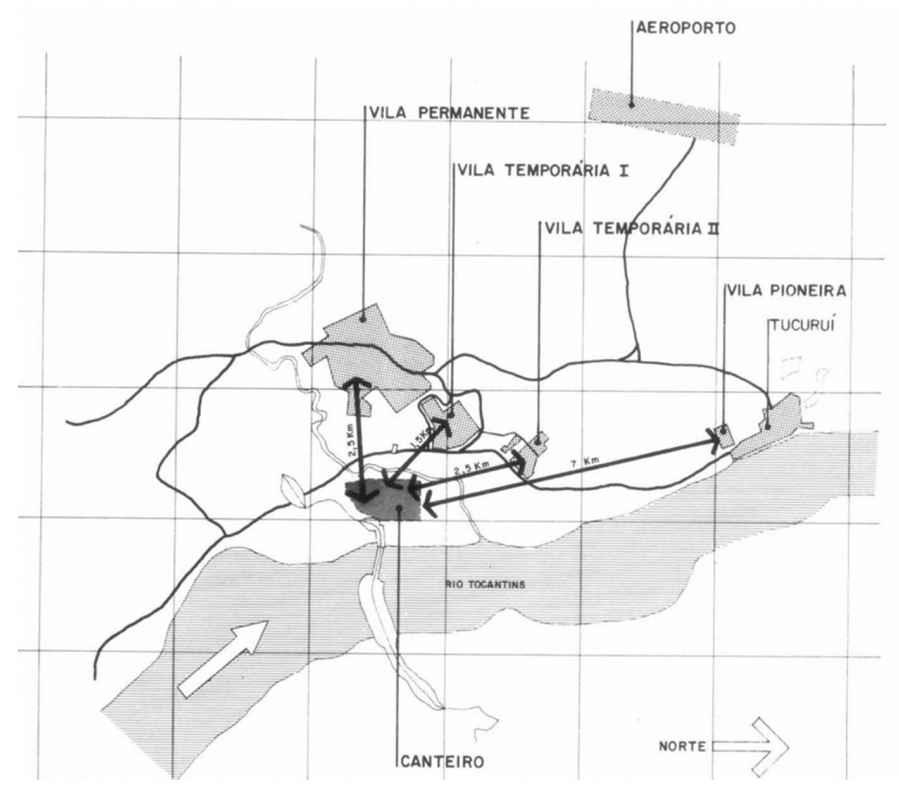

Fonte: ENGEVIX; THEMAG. UHE Tucuruí: projeto de engenharia das obras civis: consolidação da experiência. Brasília: Eletronorte, 1987. p. 342.

27 VASCONCELOS, op. cit., p. 60.

28 ELETRONORTE, op. cit., 1988, p. 342. 
A Vila Permanente, que começou a ser construída em 1976, foi a verdadeira cidade-empresa, enclave da Eletronorte no local, que deveria ser usada não apenas na fase de construção, mas também durante a operação da usina e que existe até hoje. Essa área foi projetada para abrigar 34.000 habitantes, mais de seis vezes a população de Tucuruí antes da barragem. Aproveitando a topografia local, ela foi construída no alto para oferecer uma vista panorâmica da barragem e de seu lago. Ela foi murada e cercada e a entrada possuía um portão por onde os seguranças controlavam as idas e vindas, já que o acesso era restrito. A Vila Temporária I, por sua vez, foi projetada para acomodar trabalhadores temporários e deveria ser desmontada após a inauguração da barragem. A Vila Temporária II seguiu a mesma lógica e foi construída posteriormente em 1981 para absorver o excesso de trabalhadores devido à alta taxa de rotatividade dos operários não qualificados. As vilas temporárias foram pensadas como distritos satélites da Vila Permanente, consistindo principalmente em habitações, com apenas poucos serviços. Juntas, essas vilas podiam abrigar mais de 25.000 pessoas.

Por ser uma cidade-empresa isolada, a Eletronorte considerava que, mais do que uma infraestrutura básica, era importante oferecer lugares agradáveis para se viver, a fim de convencer o pessoal (em particular os engenheiros e os executivos) a ir trabalhar nessa área remota. ${ }^{29} \mathrm{O}$ projeto urbanístico desses bairros busca, por exemplo, variar os estilos arquitetônicos das habitações e evitar construções adjacentes, para impedir a monotonia visual e aumentar a ventilação do espaço. ${ }^{30}$ Esses elementos aumentam o preço da construção de Tucuruí, mas, como aponta um documento de avaliação da consultoria responsável pelo projeto, "eles foram totalmente compensados pelos benefícios obtidos", ou seja, a permanência dos engenheiros. ${ }^{31}$

Segundo Paulo Roberto Amaro, diretor-técnico das obras de Tucuruí, eles "[foram] obrigados a criar uma infraestrutura adequada para o pessoal que saía do [região] Sul", o que também incluía "bons hospitais e escolas". ${ }^{32}$ Ele acrescenta que a questão do lazer também era central, "porque ao redor das nossas obras não [tinha] distrações - esta[va]mos praticamente isolados, [era] um campo de concentração e [dependíamos] quase exclusivamente do avião". 33 Assim, a Vila Permanente contava com escolas, um hospital, diversos serviços e lojas, opções de entretenimento, como clubes, restaurantes, bares, boates, shopping, cinema, teatro, centro comunitário e um prédio ecumênico. Diferentemente de um modelo onde a empresa gerencia todos os serviços e infraestruturas, a Eletronorte, embora responsável por esses bairros, compartilhava ou delegava parte de seu gerenciamento e manutenção. Por exemplo,

29 AMARO, Paulo Roberto. Metodologia, procedimento e metas: a experiência da Eletronorte. ANAIS DO SEMINÁRIO NACIONAL DE HISTÓRIA E ENERGIA. São Paulo: Eletropaulo/Departamento de Patrimônio Histórico, 1986. p. 125-138; FARAH, Flavio; FARAH, Marta F. S. Vilas de mineração e de barragens no Brasil: retrato de uma época. São Paulo: SAMA/IPT, 1993.

30 ENGEVIX; THEMAG, op. cit., p. 343.

31 Ibidem.

32 AMARO, op. cit.

33 Ibidem, p. 129. 
a prefeitura da Vila Permanente foi coadministrada pela Eletronorte e pela Camargo Corrêa. Aconstrutora também gerenciava os hospitais e as escolas do complexo Eletronorte, enquanto outros serviços foram delegados a outros atores privados. Como Farah e Farah apontaram, esse modelo de gestão "mista" de cidades-empresa foi cada vez mais aplicado no Brasil a partir da década de $1980 .{ }^{34}$ Embora o acesso a uma boa parte dos serviços fosse gratuito para os funcionários, esse novo esquema pressupunha que os beneficiários pagassem pelo menos uma parte do custo de vida, principalmente os trabalhadores menos qualificados, como veremos a seguir.

Como formula Wilson Quintella, vice-presidente da Camargo Corrêa na época, a Vila Permanente era uma "cidade do primeiro mundo presa no coração da selva" ${ }^{35} \mathrm{~A}$ escolha de palavras feitas por Quintella e Amaro para falar das vilas da Eletronorte é significativa, pois revela alguns dos sentimentos dos novos habitantes de Tucuruí. Apesar das muitas comodidades e serviços, Quintella acha que a cidade está "presa" na floresta e Amaro até usa o termo "campo de concentração", ambos expressando a sensação de isolamento e confinamento. Será que esse sentimento era compartilhado por todos os funcionários que viviam em Tucuruí? Ou refletia a posição de executivos deslocalizados? Essas questões nos permitirão refletir sobre outra problemática colocada pelo estabelecimento desses espaços particulares, as cidades-empresas, onde se tecem diversas relações de dominação - de classe, mas também de raça, e de gênero -, com diferentes experiências vividas, dependendo da posição social ocupada. ${ }^{36}$

\section{Composição e modo de vida nas vilas de Tucuruí}

O CANTEIRO DE OBRAS DE TUCURUí foi um local de passagem para um grande número de trabalhadores e trabalhadoras que ocuparam uma ampla variedade de cargos, desde o engenheiro até a lavadeira, do capataz ao especialista em explosivos, da secretária administrativa ao carregador. Dentro dessa diversidade, é a estratificação da população de acordo com um ranking definido por uma grade socioprofissional desenvolvida pela Eletronorte que orienta a vida dentro das vilas - da alocação de uma moradia ao acesso a determinados equipamentos (Tabela 1).

Além disso, na medida em que apenas uma parte muito pequena do pessoal era contratada diretamente pela Eletronorte - entre 3 e 9\% entre 1977 e 1986 -, a posição do empregador fazia parte da estratificação interna, assim como a situação do trabalhador (terceirizado, temporário ou estável), ou ainda se ele vivia com a família ou sozinho. A Camargo Corrêa foi responsável pela maioria das contratações do canteiro e as outras

34 FARAH; FARAH, op. cit.

35 QUINTELLA, Wilson. Memórias do Brasil grande: a história das maiores obras do país e dos homens que as fizeram. São Paulo: Editora Saraiva, 2008. p. 388.

36 SOUSA, Nair H. Bicalho. Trabalhadores pobres e cidadania: a experiência da exclusão e da rebeldia na construção civil. Uberlândia: EDUFU, 2007. 
empresas presentes na obra gerenciaram entre 20 e $25 \%$ da equipe - uma percentagem que permaneceu estável ao longo da construção. ${ }^{37}$

A taxa de rotatividade geral foi alta, atingindo cerca de 13\% em média, especialmente no início das obras quando foi atingido o pico de $32 \%$ em abril de $1978 .{ }^{38}$ Inversamente, a taxa de permanência média do pessoal era baixa, cerca de seis meses até 1980, depois vinte meses até o final das obras. É importante enfatizar que a equipe administrativa e de supervisão tinha uma taxa de permanência mais alta que a dos operários, o que também se aplica aos trabalhadores casados, qualquer fosse o seu nível. A maior parte da força de trabalho era composta por operários (qualificados e não qualificados), representando $78 \%$ do total em média. Os cargos de gerência ou supervisão representavam apenas $0,5 \%$ (Tabela 2).

Tabela 1 - Estratificação socioprofissional utilizada pela Eletronorte.

\begin{tabular}{c|c|l}
\hline Nível & Subnível & \multicolumn{1}{c}{ Tipo } \\
\hline A & 6 & Universitário superior em posição de supervisão e chefia \\
\hline B & 5 & $\begin{array}{l}\text { Universitário superior sem posição de supervisão e chefia e } \\
\text { técnico superior em posição de supervisão e chefia }\end{array}$ \\
\hline C & 3 e 4 & Técnicos e operários qualificados \\
\hline D & 1,2 e 3 & Operários não qualificados \\
\hline
\end{tabular}

Fonte: Elaboração própria com dados provenientes de ELETRONORTE. Usina Hidrelétrica de Tucuruí - Memória do Empreendimento. Brasília: coordenação técnica do departamento de projetos, 1988; ENGEVIX; THEMAG, op. cit.

Tabela 2 - Percentagem média de funcionários, de acordo com a função ocupada e o nível de estratificação socioprofissional, durante a duração das obras (1974-1987).

\begin{tabular}{l|c|c}
\hline \multicolumn{1}{c|}{ Função } & Nível & Percentagem média \\
\hline Mão de obra não qualificada & D & $33 \%$ \\
\hline Mão de obra qualificada & C & $45 \%$ \\
\hline Feitores e burocratas auxiliares & C & $11 \%$ \\
\hline Encarregados, burocratas e técnicos de nível médio & B & $7,5 \%$ \\
\hline Técnicos de nível superior e encarregados de seção & B & $3 \%$ \\
\hline Supervisão e chefia & A & $0,5 \%$ \\
\hline
\end{tabular}

Fonte: Elaboração própria com dados provenientes de ELETRONORTE, op. cit., 1988, v. 7.

37 ELETRONORTE, op. cit., 1989, p. 387.

38 Ibidem, p. 257. Na mesma época, a taxa média de rotatividade em canteiros de obras nas regiões Sul e Sudeste era de 4 a $5 \%$. 
De acordo com essas diferenças, existiam catorze tipos de casas e pelo menos quatro tipos de casas coletivas. ${ }^{39}$ Dependendo da classificação e da situação do ocupante, as casas tinham uma arquitetura e dimensões diferentes, eram construídas com materiais de melhor ou menor qualidade, ou eram isoladas ou coladas umas às outras. Da mesma forma, os clubes não eram os mesmos para operários, burocratas ou executivos. Estes últimos se beneficiavam de uma parte significativa do orçamento de construção e manutenção das "vilas", porque desfrutavam das melhores acomodações e serviços, além de uma oferta específica de lazer. ${ }^{40}$

A Vila Permanente, contando com as melhores infraestruturas e serviços, era aquela onde moravam os trabalhadores estáveis de maior nível. A Vila Permanente acolhia também a população casada dos subníveis 6, 5, 4 e 3 e uma parte da população solteira dos níveis 6, 5 e $4 .{ }^{41}$ Nessa vila, a morfologia irregular do terreno foi integrada à estratificação social, com as casas dos executivos nas áreas mais altas (ver Figura 3). Por outro lado, a maioria dos trabalhadores solteiros de nível $C$ e $D$ vivia em residências coletivas nas vilas temporárias, bem como os trabalhadores casados de nível D, o mais baixo. Essa separação cria uma forte segregação social. Por exemplo, de acordo com a classificação profissional de seus pais, uma criança estudava em uma escola da Vila Permanente ou Temporária e frequentava um clube para o nível $A, B$ ou $D$, o que excluía a convivência entre crianças as quais os pais se encontravam em lados opostos da estratificação profissional da Eletronorte. Essa situação também gera uma diferenciação entre operários mais estáveis (que moravam na Vila Permanente) e os temporários. Como nota Diana Antonaz no seu estudo sobre a cidadeempresa da Albrás-Alunorte em Bacarena, a existência de melhores escolas oferecidas aos filhos desses trabalhadores mais estáveis é de grande efeito simbólico, pois significava uma promessa de educação de bom nível para a geração seguinte desses operários que, com tanto sacrifício, se distinguiriam enfim dos proletários instáveis. ${ }^{42}$

Amaioria dos trabalhadores eram homense, até 1980, as mulheres representavam apenas $5,3 \%$ da força de trabalho. Segundo a Eletronorte, foi apenas quando as vilas residenciais foram estabelecidas e que a estrutura administrativa foi ampliada que mais mulheres foram contratadas, até atingirem um máximo de $16,9 \%$ da equipe em $1986 .{ }^{43}$ Isso reflete o fato de uma parte significativa da equipe feminina ocupar cargos relacionados à manutenção, limpeza e cozinha, além de cargos administrativos, que são de menor reconhecimento social e baixa remuneração, como apontado por Edna Casto. No entanto, em Tucuruí, as mulheres também teriam ocupado um lugar importante entre funcionários qualificados, enquanto engenheiras e técnicas, com cerca de 500 mulheres em cargos que exigiam um nível universitário, enquanto

39 ENGEVIX; THEMAG, op. cit., p. 358.

40 ELETRONORTE, op. cit., 1988, p. 206.

41 As menções "casados" e "solteiros" no texto fazem referência respectivamente ao viver com a família nas vilas da Eletronorte ou não, e não ao estado civil.

42 ANTONAZ, Diana. Na escola dos grandes projetos, a formação do trabalhador industrial na Amazônia. Dissertação (Mestrado em Engenharia) - Universidade Federal do Rio de Janeiro, Rio de Janeiro, 1995.

43 ELETRONORTE, op. cit., 1989, p. 257. 
a maioria da força de trabalho (mais de $50 \%$ ) tinha apenas o nível primário concluído. ${ }^{44}$ Esse fato é amplamente divulgado pela Eletronorte em vários de seus materiais publicitários. ${ }^{45}$ No entanto, e apesar da ausência de números precisos nas fontes, elas não parecem ter estado presentes em cargos gerenciais e executivos. ${ }^{46}$

\section{Figura 3 - Divisão por tipo de acomodação nas diferentes vilas da Eletronorte.}

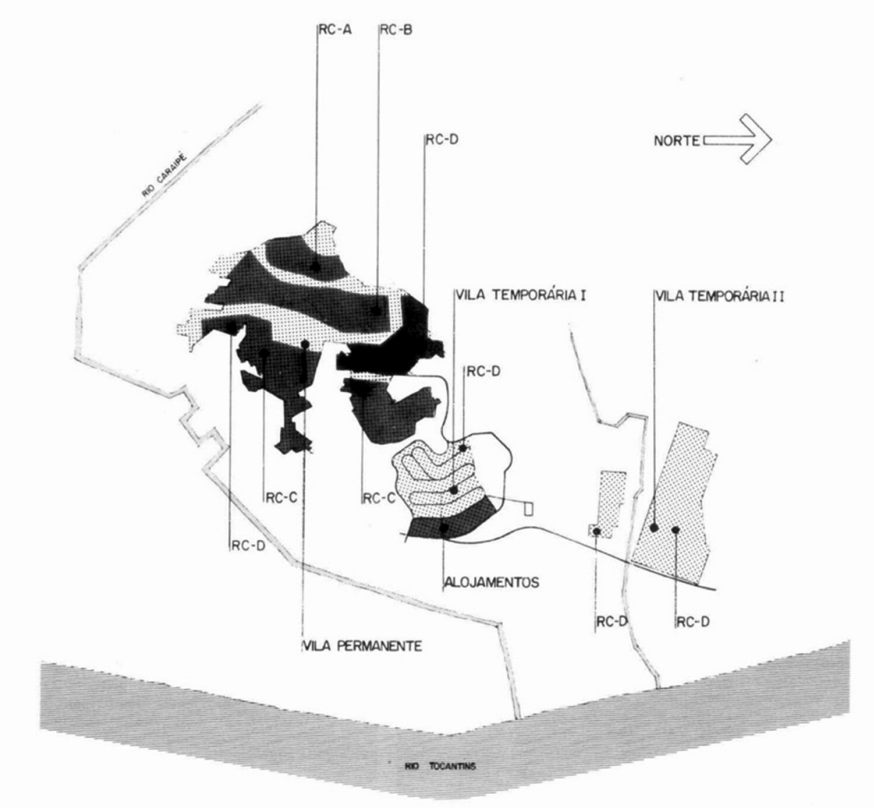

Fonte: ELETRONORTE, Usina Hidrelétrica de Tucuruí Memória do Empreendimento, p. 354.

Embora sub-representadas na equipe, as mulheres foram muito presentes na cidade-empresa, onde muitos trabalhadores viviam com suas famílias. Em alguns anos, elas representaram até um terço dos habitantes dos bairros da Eletronorte. Essa vida familiar implica também na presença de muitas crianças. Durante o período da construção, as escolas da cidade-empresa de Tucuruí acolheram cerca de 10.000 alunos por ano, do jardim de infância ao ensino médio. ${ }^{47}$ Além disso, os hospitais da Eletronorte contabilizaram mais de 10.000 nascimentos durante as obras.

O canteiro de obra de Tucuruí, localizado em uma zona com baixa densidade demográfica, necessitou uma grande mobilização de trabalhadores vindos de outros lugares. No início da construção (1975-1976), cerca de 70\% dos operários vinham das regiões Sul e Sudeste do país. Eram principalmente os barrageiros, operários qualificados ou especializados da construção civil que percorriam o país de canteiro em canteiro, no que Gustavo Ribeiro

44 LESAGE, Romain. Usina de Tucuruí - 1984. [s.I.]: Assessoria de Imprensa da Eletronorte, 1984; ELETRONORTE, op. cit., 1989, p. 258.

45 LESAGE, Romain. Usina de Tucuruí - 1979. [s.I.]: Assessoria de Imprensa da Eletronorte, 1979; LESAGE, op. cit.

46 Se não consegui encontrar números precisos, outros elementos atestam esse fato, como as assinaturas dos relatórios, as fotos e as atas das reuniões da administração, entre outros.

47 Esse número inclui também adultos em formação. 
denominou o "circuito migratório dos grandes projetos". ${ }^{48} \mathrm{O}$ restante, principalmente os operários não qualificados, jovens e solteiros, foram recrutados localmente nos estados do Pará e Maranhão. Segundo a Camargo Corrêa, responsável pela contratação de trabalhadores, o recrutamento na região Norte foi difícil. Apesar de uma grande campanha realizada até 1977, o recrutamento local não foi suficiente para atender às necessidades da obra, o que levou a uma campanha nacional no ano seguinte. ${ }^{49}$

Para trazer trabalhadores para Tucuruí, a Camargo Corrêa usou diferentes recursos. Por exemplo, campanhas eram lançadas em seus canteiros em finalização, como os das barragens de Água Vermelha e Ilha Solteira, em São Paulo, para recontratar em Tucuruí os barrageiros desmobilizados ${ }^{50}$ Comerciais eram transmitidos na televisão e no rádio, e anúncios foram publicados na imprensa. Em certas áreas do Norte e Nordeste, carros de som percorriam as ruas para informar sobre o recrutamento. A empresa também usou "recrutadores-viajantes" que percorriam diferentes cidades e vilarejos para contratar grupos inteiros de trabalhadores que eles levavam diretamente para Tucuruí mediante o pagamento de uma taxa. A empresa também incentiva os trabalhadores em férias a trazer amigos ou familiares para trabalhar em Tucuruí quando eles retornassem. ${ }^{51}$ Assim como a divulgação em outros canteiros de obras, a ideia era fazer funcionar a "rádio peão" - uma referência às redes informais, mas muito eficazes, de comunicação entre os trabalhadores da construção civil. ${ }^{52}$ Chegando em Tucuruí, a seleção era feita inicialmente apenas por um exame médico, mas, a partir de 1977, um exame psicotécnico se tornou necessário.

Se as condições de vida nos bairros da Eletronorte são, em muitos aspectos, melhores do que as da cidade de Tucuruí, para os operários não qualificados elas permanecem bastante precárias. Ao contrário de executivos e funcionários de nível superior, e apesar de algumas dificuldades iniciais de recrutamento, a necessidade de operários não qualificados, os chamados peões de obra, é menor em um país com uma grande reserva laboral não qualificada. No que diz respeito às moradias coletivas por exemplo, são frequentes os relatos de excesso de ocupação, problemas de higiene e falta de privacidade. ${ }^{53}$ Durante o pico das obras, o contingente era muito superior ao planejado, fazendo com que os quartos fossem superlotados. Alguns mediam apenas $2 \times 2 \mathrm{~m}$, mas eram ocupados por oito pessoas e chegavam a custar 4.000 cruzeiros por mês, o que representava $47 \%$ do salário mínimo na época. ${ }^{54}$

48 RIBEIRO, Gustavo Lins. Empresas transnacionais: um grande projeto por dentro. São Paulo: Marco Zero/ Anpocs, 1991. p. 159-163.

49 ENGEVIX; THEMAG, op. cit.

50 Geisel inaugura usina, O Estado de S. Paulo, São Paulo, p. 1, 28 sep. 1978.

51 ELETRONORTE, op. cit., 1988, vol. 7. Sobre o recrutamento informal nos canteiros do Brasil, ver: LIMA, Jacob Carlos; CONSERVA, Marinalva de S. Redes sociais e mercado de trabalho: entre o formal e o informal. Política \& Trabalho, João Pessoa, n. 24, p. 73-98, 2006.

52 É curioso notar que o termo "rádio peão" agora é comumente usado no mundo corporativo para qualificar rumores e informações não oficiais que circulam entre os funcionários. Originalmente, esse termo era usado no mundo da construção civil e não tinha necessariamente uma conotação negativa.

53 FARAH; FARAH, op. cit., p. 60-64.

54 Ibidem, p. 61; VASCONCELOS, op. cit., p. 58-68; ENGEVIX; THEMAG, op. cit., p. 353. 
Além da precariedade, os trabalhadores também eram controlados nos espaços de vida, um fato intimamente ligado às dinâmicas estabelecidas pela cidade-empresa. Entretanto, somente a coerção não era suficiente para controlar esse contingente elevado, em uma área isolada. Assim, Rocha e Gomes explicam que a Eletronorte e a Camargo Corrêa agiam de duas maneiras: com medidas repressivas contra manifestações de descontentamento dos trabalhadores e com mecanismos de pacificação para evitar explosões durante os momentos de calma. ${ }^{55}$ Além dos elementos previstos no plano urbanístico, foram oferecidas comodidades aos trabalhadores, como um repetidor de televisão que transmitia os programas do maior canal nacional, a Rede Globo. A Camargo Corrêa e a Eletronorte também organizavam eventos musicais, culturais e esportivos para entreter a equipe. Além disso, foi dada especial atenção à alimentação, em especial a presença de "carne em grandes quantidades" e à pontualidade dos pagamentos. ${ }^{56}$ Como aponta Edna Castro, no contexto amazônico novas formas de paternalismo são elaboradas em uma situação de "fronteira industrial", profundamente marcada pela presença do Estado (aqui representado pela Eletronorte) e onde evoluem as estratégias de fixação da mão de obra. ${ }^{57}$ Assim, todos esses recursos foram considerados essenciais para ocupar os trabalhadores nas horas de repouso e evitar a emergência de conflitos, seja com a empresa e seus agentes de segurança ou entre trabalhadores.

O estudo de Farah e Farah é uma fonte interessante para entender o sentimento dos habitantes nas vilas da Eletronorte. ${ }^{58}$ Segundo os autores, o sentimento de isolamento discutido no início do texto era uma queixa frequente. Na época, o acesso a comunicações, como o telefone, era restrito, as viagens aéreas eram muito caras, e as distâncias a serem percorridas de ônibus ou barco eram muitas vezes impraticáveis. Esse sentimento parece ser compartilhado entre aqueles do mais alto e do baixo escalão. No entanto, as razões para esse sentimento diferem: os primeiros reclamavam da diferença com os centros urbanos e os segundos sofriam com o isolamento de suas famílias e grupos sociais, que não podiam visitar. ${ }^{59}$ Outra questão levantada era a segregação de pessoas solteiras, que eram excluídas fisicamente - por viverem em moradias coletivas mais distantes - e socialmente - pois eram vistas pelas famílias com desaprovação. ${ }^{60}$ Como a cidade-empresa é um local criado para maximizar a produtividade do trabalho e manter a ordem, certas categorias da população não eram levadas em consideração. Assim, esposas não encontravam trabalho no local,

55 ROCHA, Gilberto de Miranda; GOMES, Claudemir Brito, A construção da usina hidrelétrica e as transformações espaciais na região de Tucuruí. In: TRINDADE JR., Saint-Clair Cordeiro da; ROCHA, Gilberto de Miranda (orgs.). Cidade e empresa na Amazônia: gestão do território e desenvolvimento local. Belém: Paka-Tatu, 2002. p. 18.

56 Revista O Empreiteiro, n. 148, maio 1980 apud CAMPOS, Pedro Henrique P., A ditadura dos empreiteiros: as empresas nacionais de construção pesada, suas formas associativas e o Estado ditatorial brasileiro, 19641985. Tese (Doutorado em História) - Universidade Federal Fluminense, Niterói, 2012. p. 250-251.

57 CASTRO, Edna. Industrialização, Transformações Sociais e Mercado de Trabalho. Papers do NAEA, n. 23, 1994.

58 FARAH; FARAH, op. cit.

59 Ibidem, p. 62.

60 Ibidem, p. 63-64. 
adolescentes não encontravam perspectivas educacionais e havia uma ausência total de estruturas para os idosos. ${ }^{61}$

\section{«A revolta chegou nos canteiros »}

EM ABRIL 1980, um incidente entre trabalhadores e agentes de segurança desencadeou uma revolta que revelou muito sobre as condições de trabalho nesses grandes projetos de desenvolvimento, bem como os problemas específicos de um canteiro na floresta. A barragem de Tucuruí era, na época, o segundo maior canteiro de obras do Brasil e estava localizado em uma zona particularmente isolada. Tudo começa com um episódio típico do Sábado Santo (véspera do domingo de Páscoa), conhecido como "a malhação do Judas". Nesse ritual católico popular, uma efígie de Judas Iscariotes, feita de tecido e serragem, é arrastada e espancada pelas ruas, antes de ser queimada no final da procissão. É comum vestir o boneco com placas, máscaras ou outros elementos representando personagens rejeitados pela população, como políticos ou técnicos de futebol. Seguindo essa tradição de brincadeira crítica, os trabalhadores optaram por vestir o seu Judas como um dos guardas de segurança da Camargo Corrêa, decorado com pôsteres criticando a empresa. ${ }^{62}$

Mais de 2.000 trabalhadores participaram da procissão que devia terminar no meio do canteiro de obras, mas os guardas do canteiro, fortemente armados, reprimem o evento e prendem os que são identificados como líderes. ${ }^{63}$ Segundo as fontes analisadas, após a repressão um tumulto acontece, carros são queimados, um supermercado local é saqueado e uma cantina da empresa é destruída, junto com vários apartamentos. Durante a rebelião, os trabalhadores exigiram um aumento de $100 \%$ em seus salários, melhorias em suas acomodações e protestaram contra a falta de carne. A empresa chamou a polícia, que reprimiu a rebelião com cartuchos de gás lacrimogêneo e até munição real. Alguns relatos falam de mortos nessa repressão, outros apenas de feridos. ${ }^{64} \mathrm{~A}$ oposição ao governo no Congresso aproveitou a oportunidade para criticar o regime que permitiria que grupos privados explorassem os trabalhadores brasileiros e apresentando seu "apoio irrestrito" aos operários de Tucuruí. ${ }^{65}$

Essa rebelião é uma das mais significativas que um canteiro brasileiro vivera até então, como sublinha a revista do setor de construção civil O Empreiteiro, que intitulou sua primeira página "A revolta chegou aos canteiros de obras. Você está preparado?". ${ }^{66}$ Desde 1978 as

61 Ibidem

62 QUINTELLA, op. cit., p. 199-224.

63 DIOCESE DE NOVO IGUAÇU, Cartilha sobre o desemprego, 6 set. 1983, Arquivo Nacional - COREG, CISABR-AN-BSB-VAZ-082-0124.

64 Camargo Corrêa ocasiona mortes em rebelião no norte do Pará, Tribuna da Imprensa, Brasília, p. 2 , 7 abr. 1980; Revista O Empreiteiro, n. 148, maio 1980 apud CAMPOS, op. cit., p. 449-450; Empresa desmente mortes em Tucuruí, O Estado de S. Paulo, São Paulo, p. 25, 1980.

65 Tucuruí: sugerida intervenção, O Estado de S. Paulo, São Paulo, p. 19, 9 abr. 1980.

66 Revista O Empreiteiro, n. 148, maio 1980 apud CAMPOS, op. cit., p. 288. Outras revoltas significativas da construção civil que a revista não cita ocorreram durante a construção de Brasília nos anos 1950 e 1960 e na construção do metrô do Rio de Janeiro no final dos anos 1970. 
principais greves dos trabalhadores ocorriam em fábricas em todo o país, e a revolta em Tucuruí marca a chegada de greves em um outro espaço de trabalho. Se os trabalhadores de Tucuruí possuíam certas "vantagens", concedidas pela empresa principalmente devido às condições de isolamento do local, mas também pensadas para evitar esse tipo de rebelião como visto acima, elas não apagavam a violenta tensão social frequentemente presente nos canteiros de obras.

Assim, as condições de trabalho em Tucuruí, especialmente as dos trabalhadores não qualificados, refletem a realidade da época. Como mostram diversos autores, nos principais canteiros de obras durante a ditadura, acidentes, mas também o não cumprimento da legislação trabalhista e medidas abusivas, eram comuns. ${ }^{67}$ Por exemplo, um artigo de imprensa relata casos julgados pela Justiça do Trabalho em que as reduções de pagamento devido aos serviços prestados pela empresa (moradia, alimentação e outros) podiam chegar a $70 \%$ do valor do salário total. ${ }^{68}$ Outro problema comum era a alta taxa de acidentes. Como sublinha Campos, na década de 1970, o Brasil foi um dos países com mais acidentes de trabalho no mundo, com o setor de construção no topo das estatísticas. ${ }^{69}$

Em matéria de acidentes de trabalho, as publicações da Eletronorte apresentam números de maneira pouco clara, como atesta a única fonte oficial sobre as mortes durante a obra: uma tabela gráfica incompreensível (Figura 5). A própria curva, que apresenta dados mensais, mostra um número significativo de óbitos, mas a apresentação escolhida para resumir os números indica apenas o valor médio por mês dos óbitos em um ano, em uma apresentação confusa que pode levar a entender que esse valor é anual. A curva de acidentes apresenta o mesmo problema com a apresentação de uma média anual do número de acidentes por mês (Figura 4). No entanto, esses dados permitem ao menos estimar a amplitude desse tipo de fenômeno em Tucuruí.

Figura 4 - Acidentes em função do "coeficiente de gravidade".

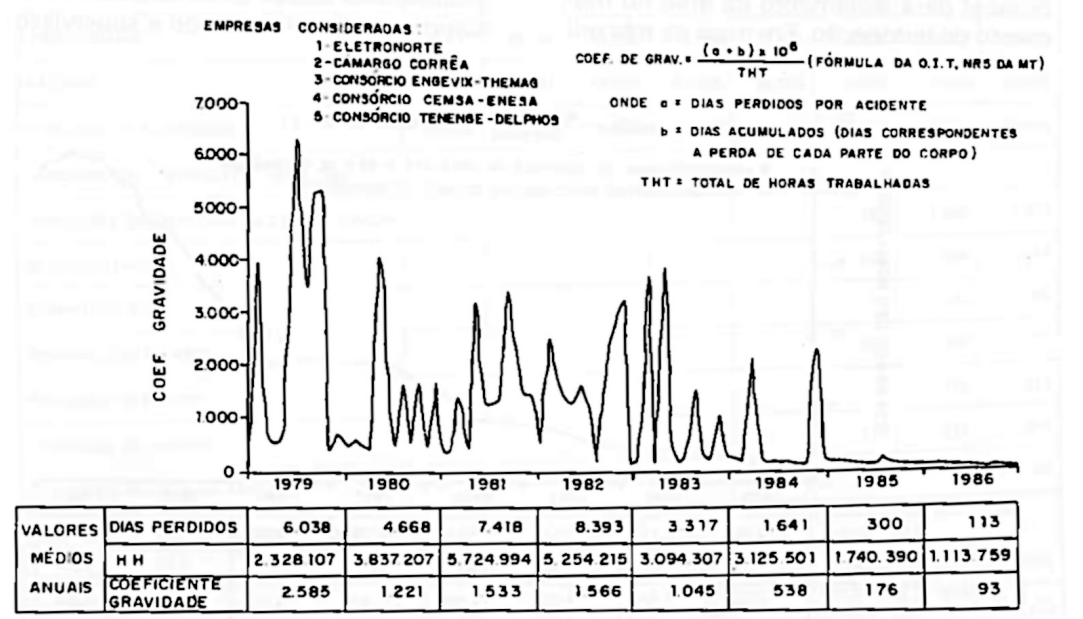

Fonte : ELETRONORTE, op. cit., 1989, p. 394.

67 Ibidem, p. 441-447; BROCHIER, Christophe. L'apprentissage " sur le tas » dans les chantiers brésiliens. Geneses, v. 56, n. 3, p. 97-116, 2004; ANTONAZ, op. cit.

68 Camargo Corrêa ocasiona ..., op. cit., p. 2.

69 CAMPOS, op. cit. 
No setor da construção civil, os acidentes mais frequentes são o colapso e as projeções de pedras, esmagamentos ou choques por máquinas, choques elétricos, quedas, soterramento, compressões, ricochetes de projéteis, acidentes relacionados a explosões e afogamentos. Esses acidentes são algumas vezes fatais, mas geralmente resultam na perda de um membro. ${ }^{70}$ Esses dados ajudam a entender o cálculo do "coeficiente de gravidade" de um acidente realizado pela Eletronorte que é expresso em dias de trabalho perdidos em função dos dias acumulados, esses são "dias correspondentes à perda de um membro" em relação ao total de horas trabalhadas (Figura 4). Em relação aos óbitos, é importante destacar o número significativo de mortes de mulheres, quase tão elevado quanto os de homens. Como elas não eram muito presentes no canteiro de obras, é difícil explicar esses números, portanto, pode-se presumir que a curva de mortes não represente apenas aquelas relacionadas a acidentes de trabalho, mas englobe também aquelas que aconteceram nos hospitais da empresa.

Essa alta taxa de acidentes, assim como as violações das leis trabalhistas, está relacionada ao baixo controle estatal nos canteiros de obras. Apesar de alguns autores apontarem uma característica paternalista nos canteiros de obras, que caracterizariam relações de trabalho singulares no setor da construção, a estreita relação do regime militar com os empregadores da construção também promovia um clima de laissez-faire. ${ }^{71}$ Além disso, a ideologia do regime militar que buscava identificar e perseguir inimigos internos também dificultava a organização dos trabalhadores, que corriam o risco de serem reprimidos. A Eletronorte, como órgão estatal, possuía, por exemplo, sua própria Divisão de Segurança e Inteligência (DSI), que circulava informações sobre o canteiro, principalmente as relacionadas a conflitos. A Eletronorte e a Camargo Corrêa estabeleceram um importante sistema de controle da força de trabalho no canteiro e nas zonas residenciais, com a presença de vários agentes de segurança (cerca de 115) e uma organização do trabalho particular. ${ }^{72}$ Nesse contexto, mudanças no ritmo do trabalho e a implementação de uma rotação das equipes sem interrupção do canteiro são formas de evitar longos períodos de ociosidade coletiva, além de servir para o rápido avanço da obra. A Camargo Corrêa é conhecida por sua brutalidade para com os trabalhadores e pela instalação de um controle "ostensivo" em seus canteiros de obras. ${ }^{73}$ Nesse sentido, o clima de repressão no canteiro de obras é um problema que também é constantemente apontado. Nas palavras de um operário: "Embora eles não portem armas e, às vezes, ganhem o mesmo que um trabalhador de nível um ou dois, só porque usam o uniforme marrom, eles nos tratam com violência e discriminação". ${ }^{4}$

70 LIMA JÚNIOR, Jófilo Moreira; DIAS, Luis Alves; LÓPEZ-VALCÁRCEL, Alberto. Segurança e saúde no trabalho da construção: experiência brasileira e panorama internacional. Brasília: Organização Internacional do Trabalho, Escritório do Brasil, 2005.

71 CAMPOS, op. cit. Sobre o paternalismo no setor da construção civil, ver: MORICE, Alain. Les « pions » du bâtiment au Brésil. Quand le capital se fait rebelle au salariat. Genèses. Sciences sociales et histoire, v. 7, n. 1, p. 5-32, 1992; COSTA, Luciano Rodrigues. Les relations de classes sur les chantiers brésiliens: exploitation, contrôle et confiance. Brésil(s). Sciences humaines et sociales, n. 8, p. 123-142, 2015; CASTRO, op. cit.

72 ELETRONORTE, op. cit., 1989, p. 396

73 CAMPOS, op. cit., p. 451.

74 Camargo Corrêa ocasiona..., op. cit., p. 2. 
Entre o controle exercido pela Camargo Corrêa no canteiro e o da Eletronorte nas vilas, a cidade de Tucuruí era chamada de "cidade livre". Nos dias de descanso e pagamento, os trabalhadores frequentavam a cidade velha de Tucuruí para visitar bares e bordéis, e episódios de violência eram frequentes. Segundo a imprensa, mais de 4.000 trabalhadoras do sexo trabalhavam em Tucuruí, muitas vindo de Cametá ou Belém para atender à demanda do canteiro nos dias de pagamento. ${ }^{75} \mathrm{~A}$ "cidade livre" representava de certa maneira o inverso do espaço social controlado, monitorado e fechado da Eletronorte, mas também era livre de planejamento, ordem, segurança e acesso a serviços públicos. Enquanto a maioria dos trabalhadores da barragem tinha acesso a água, eletricidade, sistema de esgoto, educação, saúde, entre outros serviços públicos e instalações urbanas e de lazer fornecidas pela Eletronorte, a população (antiga e nova) da velha Tucuruí vivia em grande parte em condições totalmente precárias. A prefeitura de Tucuruí não possuía o mesmo orçamento da Eletronorte e enfrentava a multiplicação desordenada de sua população. ${ }^{76}$

\section{Figura 5 - Curva de óbitos}

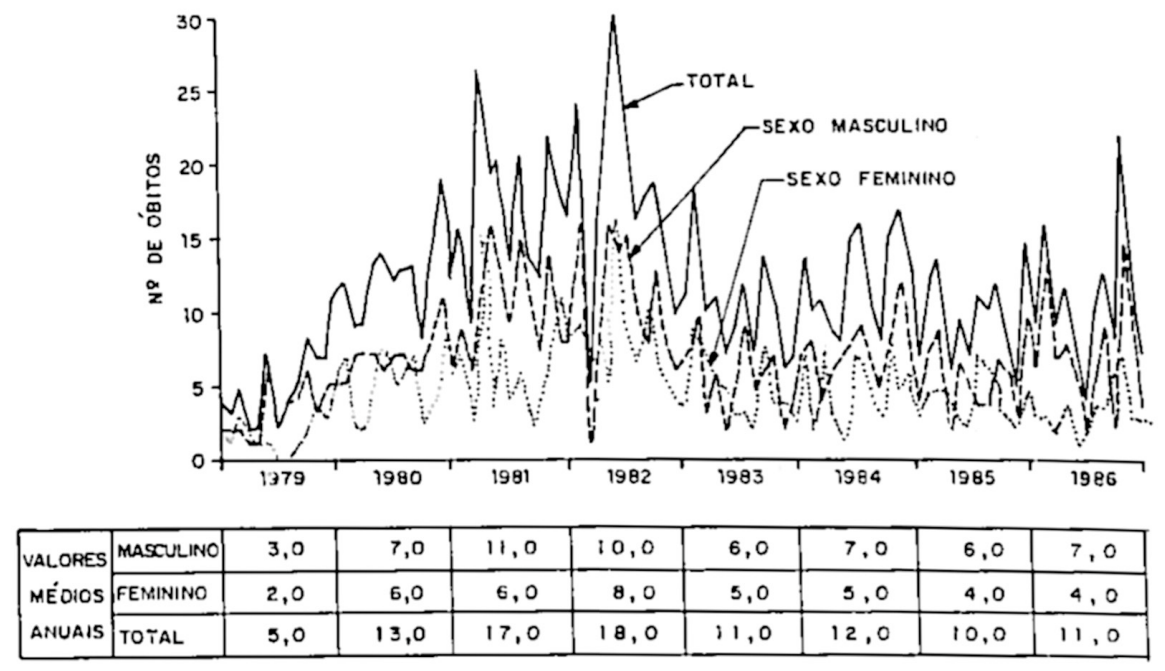

Fonte: Eletronorte, op. cit., 1989, p. 394.

A rebelião de 1980 acaba por ceder à repressão da polícia e a Camargo Corrêa sai vencedora sem ter negociado nada com os trabalhadores. Aqueles identificados como líderes foram demitidos, após uma investigação do departamento de inteligência da Eletronorte. ${ }^{77}$ No final daquele ano, a construção do sistema de transmissão e da estrutura de concreto de Tucuruí absorvia $93 \%$ do orçamento da Eletronorte. Pagamentos atrasados a fornecedores devido a cortes no orçamento causaram ansiedade entre os trabalhadores que temiam demissões, e a centelha de outra rebelião ressurgiu, mas foi rapidamente extinta. O diretor técnico da

75 Dados da Secretaria de Saúde do Estado do Pará apud PINTO, Lúcio Flávio. O governo não cumpre suas próprias determinações. Jornal Resistência, ed. 41, out. 1982.

76 ROCHA; GOMES, op. cit., p. 43.

77 DSI/PM/PARÁ, Humberto Farias Baliero - Agitador na barragem de Tucuruí, 1981, Arquivo Nacional - COREG, Informação n. ${ }^{\circ}$ SNIGK0013158. 
Eletronorte, Fausto César Vaz Guimarães, tranquiliza a imprensa declarando que todas as preocupações são infundadas e que o trabalho continua "em um grande espírito de colaboração e entendimento" entre a empresa e os trabalhadores. ${ }^{78}$

\section{Conclusão}

A IMPLANTAÇÃO DA BARRAGEM de Tucuruí desencadeou vários processos em larga escala, levando a recomposições sociodemográficas em torno da cidade de Tucuruí e do futuro reservatório. Este artigo se concentrou no estabelecimento e na administração do canteiro de obras e da cidade-empresa do grande projeto da UHE Tucuruí pelo conjunto privado-estatal representado pela Camargo Corrêa e pela Eletronorte. A partir do estudo da composição social dos trabalhadores e trabalhadoras dessa obra, assim que da maneira em que suas vidas, trabalho e rebeliões foram controlados nesse espaço emergem duas reflexões principais.

Primeiramente surge um questionamento sobre o uso de empresas pelo regime ditatorial para realizar o seu projeto para a Amazônia baseado na expansão do capitalismo e na densificação demográfica da região. É a Eletronorte, uma empresa pública do setor elétrico, e não um órgão do Estado, que lança o primeiro ato que desencadeia o processo de implantação de Tucuruí, quando estabelece planos e procedimentos para acolher seus funcionários e controlar o seu trabalho. Porém, é a empresa privada de construção civil Camargo Corrêa que gerenciava de facto tanto o trabalho (canteiro) quanto a vida (cidade-empresa) e até os serviços (escola, hospital) no entorno da obra da UHE Tucuruí. Juntas, a Eletronorte e a Camargo Corrêa desempenharam papéis que iam muito além da construção civil, constituindo-se não apenas enquanto atores que transformam o território, mas também enquanto sujeitos políticos que o administram. Assim, atores públicos e privados que invadiram a realidade dessa pequena cidade nos arredores do rio Tocantins, impuseram efetivamente dinâmicas particulares, incorporando ou transcendendo o papel Estado.

A segunda reflexão diz respeito a esse local particular chamado cidade-empresa na Amazônia. Se a cidade-empresa foi construída do zero, ela não é em nada uma criação ex nihilo. A concepção desse local revela as representações prévias da ordem social dos atores que a implantaram, como puderam notar outros estudos que se interessaram por esse tipo de espaço, ${ }^{79}$ no caso aqui estudado os engenheiros e técnicos vindos em sua maioria do Sul e Sudeste do Brasil. Enquanto negação dos padrões regionais de ocupação, ${ }^{80}$ a cidade-

78 ASSUNÇÃO, Clóvis. Tucuruí não paga fornecedor. O Estado de S. Paulo, São Paulo, p. 34, 18 dez. 1980.

79 GRANDIN, Greg. Fordlandia: the rise and fall of Henry Ford's forgotten jungle city. New York: Metropolitan Books, 2009; CRONON, William. Voyage à Kennecott: les voies de sortie de la ville? In: Nature et récits: Essais d'histoire environnementale. Bellevaux: Dehors, 2016. p. 97-132; GREEN, Hardy. The Company Town: The Industrial Edens and Satanic Mills That Shaped the American Economy. Basic Books: New York, 2010; FARAH; FARAH, op. cit.; ACKER, Antoine. Volkswagen in the Amazon: The Tragedy of Global Development in Modern Brazil. Cambridge: Cambridge University Press, 2017.

80 BECKER, Bertha K. Geopolítica da Amazônia: a nova fronteira de recursos. Rio de Janeiro: Zahar Editores, 1982. 
-empresa da Eletronorte em Tucuruí, produziu efeitos particularmente negativos e "muito mais pronunciados" do que em outros casos semelhantes no Brasil, como aponta o estudo de Farah e Farah. ${ }^{81} \mathrm{~A}$ transposição de uma ordem social (em si mesma artificial) exterior em um lugar totalmente diferente (a Amazônia) suscita diversos problemas que serão expressos por conflitos diretos, como a rebelião, e indiretos, como a sensação de controle, reproduzindo relações sociais de dominação.

Recebido em 01/07/2020

Aprovado em 15/08/2020 